\title{
Synthesis, Characterization, and Handling of Eull-Containing Complexes for Molecular Imaging Applications
}

\author{
Lina A. Basal and Matthew J. Allen* \\ Department of Chemistry, Wayne State University, Detroit, MI, United States
}

Considerable research effort has focused on the in vivo use of responsive imaging probes that change imaging properties upon reacting with oxygen because hypoxia is relevant to diagnosing, treating, and monitoring diseases. One promising class of compounds for oxygen-responsive imaging is Eull-containing complexes because the Eu/IIII redox couple enables imaging with multiple modalities including magnetic resonance and photoacoustic imaging. The use of Eull requires care in handling to avoid unintended oxidation during synthesis and characterization. This review describes recent advances in the field of imaging agents based on discrete Eull -containing complexes with

OPEN ACCESS

Edited by:

Zsolt Baranyai,

Bracco Imaging S.p.a, Italy

Reviewed by:

Mark Woods,

Portland State University,

United States

Jean-Claude Georges Bunzli,

École Polytechnique Fédérale de

Lausanne, Switzerland

*Correspondence:

Matthew J. Allen

mallen@chem.wayne.edu

Specialty section:

This article was submitted to

Inorganic Chemistry,

a section of the journal

Frontiers in Chemistry

Received: 16 January 2018 Accepted: 28 February 2018

Published: 19 March 2018

Citation:

Basal LA and Allen MJ (2018) Synthesis, Characterization, and

Handling of Eull-Containing Complexes for Molecular Imaging Applications. Front. Chem. 6:65. doi: 10.3389/fchem.2018.00065 specific focus on the synthesis, characterization, and handling of aqueous Eu" ${ }^{\text {II }}$-containing complexes.

Keywords: chelating ligands, contrast agents, coordination chemistry, divalent europium, lanthanides, molecular imaging probes

\section{INTRODUCTION}

Divalent europium is a paramagnetic ion with photophysical and electrochemical properties that can be modulated with coordination chemistry (Gansow et al., 1977; Yee et al., 1980, 1983; Sabbatini et al., 1982, 1984; Antonio and Soderholm, 1996; Jiang et al., 1998; Shipley et al., 1999; Burai et al., 2000; Soderholm et al., 2002; Botta et al., 2003; Christoffers and Starynowicz, 2008; Gamage et al., 2010; Pan et al., 2011; Garcia and Allen, 2012a,b; Gál et al., 2013; Kelly et al., 2015; Kuda-Wedagedara et al., 2015; Regueiro-Figueroa et al., 2015; Allen, 2016; Ekanger et al., 2016a, 2017; Jin et al., 2016; Vanek et al., 2016; Basal et al., 2017a,b; Burnett et al., 2017; Kawasaki et al., 2017; Corbin et al., 2018; Jenks et al., 2018). Because of these tunable properties, divalent europium complexes have potential use as molecular-imaging probes that sense $\mathrm{O}_{2}$, which is important because $\mathrm{O}_{2}$ imbalances are often correlated with disease (Shweiki et al., 1992; Barnham et al., 2004; Mattson, 2004; Lin and Beal, 2006; Park et al., 2008; Facciabene et al., 2011). One promising technique to investigate oxygenation is contrast-enhanced magnetic resonance imaging (MRI) with $\mathrm{Eu}^{\mathrm{II}}$-containing complexes. Divalent europium was proposed as a $\mathrm{pO}_{2}$ sensor for MRI (Burai et al., 2000) because divalent europium acts as a $T_{1}$-shortening contrast agent for MRI until it is oxidized to Eu ${ }^{\text {III }}$, which shows no measurable $T_{1}$-shortening ability at imaging-relevant concentrations and field strengths ( $\leq 6 \mathrm{mM}$ ) (Ekanger et al., 2016a; Basal et al., 2017b). Recently, the first example of in vivo imaging using a $\mathrm{Eu}^{\mathrm{II}}$-containing contrast agent was reported (Ekanger et al., 2015), and other in vivo examples followed (Ekanger et al., 2016b; Funk et al., 2016; Basal et al., 2017a). The recent advancement of $\mathrm{Eu}^{\mathrm{II}}$-containing complexes as $\mathrm{O}_{2}$ sensors for molecular imaging and the unique experimental challenges of characterizing and handling air-sensitive $\mathrm{Eu}^{\mathrm{II}}$-containing 
complexes inspired this review. Unlike $\mathrm{Gd}^{\mathrm{III}}$, which is a commonly studied ion for $\mathrm{MRI}, \mathrm{Eu}^{\mathrm{II}}$ is air-sensitive and requires careful handling techniques because $\mathrm{Eu}^{\mathrm{II}}$ oxidizes to $\mathrm{Eu}^{\mathrm{III}}$ when exposed to $\mathrm{O}_{2}$. Many researchers who might be interested in $\mathrm{Eu}^{\mathrm{II}}$ likely have experience with $\mathrm{Gd}^{\mathrm{III}}$. However, because of the crucial differences in preparation and handling between $\mathrm{Eu}^{\mathrm{II}}$ and $\mathrm{Gd}^{\mathrm{III}}$, this review focuses on the synthesis, handling, and characterization of identity and purity of Eu ${ }^{\mathrm{II}}$ containing complexes relevant to molecular imaging (Figure 1). For measurements of molecular-imaging-relevant properties for MRI, readers are referred elsewhere (Caravan et al., 1999; Burai et al., 2000, 2002; Tóth et al., 2001; Botta et al., 2003; Garcia et al., 2011, 2012; Garcia and Allen, 2012b; Ekanger et al., 2014, 2015, 2016a,b; Basal et al., 2017a,b; Lenora et al., 2017; Pierre et al., 2018). Because this review is focused on techniques for handling and characterizing discrete, air-sensitive Eu ${ }^{\mathrm{II}}$ containing complexes for molecular imaging, we do not describe other divalent lanthanide complexes, nanoparticles, imaging probes, or nonaqueous $\mathrm{Eu}^{\mathrm{II}}$-containing complexes. Readers are referred elsewhere for details of those subjects (Evans, 2000; Dorenbos, 2003; Bochkarev, 2004; Bottrill et al., 2006; le Masne de Chermont et al., 2007; Kuda-Wedagedara and Allen, 2014; Pierre et al., 2014; Ekanger and Allen, 2015; Angelovski, 2016; Edelmann, 2016; Wang et al., 2017).

\section{SYNTHESIS OF Eu"II-CONTAINING COMPLEXES}

In this section, we describe procedures for the preparation of $\mathrm{Eu}^{\mathrm{II}}$-containing complexes using the ligands depicted in Figure 2. These procedures are divided into two general strategies (Figure 3): (1) chemical or electrochemical reduction of $\mathrm{Eu}^{\mathrm{III}}$-containing complexes or mixtures of $\mathrm{Eu}^{\mathrm{III}}$ salts and ligands and (2) metalation of ligands with $\mathrm{Eu}^{\mathrm{II}}$ salts. Depending on the route used to generate $\mathrm{Eu}^{\mathrm{II}}$-containing complexes, different techniques are appropriate to evaluate the identity and purity of the resulting complexes. These characterization techniques and strategies for effectively handling solutions of $\mathrm{Eu}^{\mathrm{II}}$-containing complexes for analyses are described in the handling section of this article.

\section{Reduction of Eu'll to Produce Eu"l-containing Complexes}

In the process of forming $\mathrm{Eu}^{\mathrm{II}}$-containing complexes, $\mathrm{Eu}^{\mathrm{III}}$ is often reduced using electrochemical or chemical methods. Transient formation of detectable amounts of $\mathrm{Eu}^{\mathrm{II}}$-containing complexes can be achieved using cyclic voltammetry, and isolable $\mathrm{Eu}^{\mathrm{II}}$-containing complexes can be obtained through electrochemical or chemical reduction of either $\mathrm{Eu}^{\mathrm{III}}$-containing complexes or mixtures of $\mathrm{Eu}^{\mathrm{III}}$ with ligands. The most favorable route to form a $\mathrm{Eu}^{\mathrm{II}}$-containing complex should be determined based upon the ligand and the type of analysis that is needed.

\section{Transient Formation of Eu" -Containing Complexes From Cyclic Voltammetry}

To obtain information about the reduction and oxidation potentials of $\mathrm{Eu}^{\mathrm{II}}$-containing complexes, several research groups have formed $\mathrm{Eu}^{\mathrm{II}}$-containing complexes transiently using cyclic voltammetry. A description of air-free electrochemical techniques used for cyclic voltammetry or bulk electrolysis to form $\mathrm{Eu}^{\mathrm{II}}$-containing complexes is described in the handling section of this review. When reducing $\mathrm{Eu}^{\mathrm{III}}$ to form $\mathrm{Eu}^{\mathrm{II}}$, two routes are commonly taken: the corresponding Eu ${ }^{\mathrm{III}}$-containing complexes are synthesized and purified before electrolysis, such as in the case of Eu-containing complexes of 8, 20, 21, 25, 26, 27, 31-34, and 39 (Gansow et al., 1977; Yee et al., 1980, 1983; Burai et al., 2003; Vanek et al., 2016; Basal et al., 2017a; Burnett et al., 2017). Alternatively, Eu ${ }^{\mathrm{III}}$ salts-such as $\mathrm{Eu}(\mathrm{OTf})_{3}, \mathrm{EuCl}_{3}$, or $\mathrm{Eu}\left(\mathrm{NO}_{3}\right)_{3}$-are dissolved in the presence of ligands, enabling the formation of complexes upon electrolysis of $\mathrm{Eu}^{\mathrm{III}}$ to $\mathrm{Eu}^{\mathrm{II}}$, such in the case of Eu-containing complexes of 1-8, 10, 11, 13-15, 20-23, 28-30, and 35-38 (Yee et al., 1980, 1983; Sabbatini et al., 1984; Burai et al., 2002, 2003; Botta et al., 2003; Gamage et al., 2010; Gál et al., 2013; Regueiro-Figueroa et al., 2015). In these experiments, cyclic voltammetry peaks that are different than the peaks for $\mathrm{Eu}_{\mathrm{aqua}} \mathrm{II}$ /II or the ligand (if the ligand is redox active in the potentials spanned by the voltammogram) are attributed to the formation of Eu $\mathrm{II}^{\mathrm{III}}$-containing complexes (Figure 4).

For the selection of an appropriate route, consideration of ligand structure and solubility is necessary. For example, ligands that readily form complexes with $\mathrm{Eu}^{\mathrm{II}}$ upon reduction

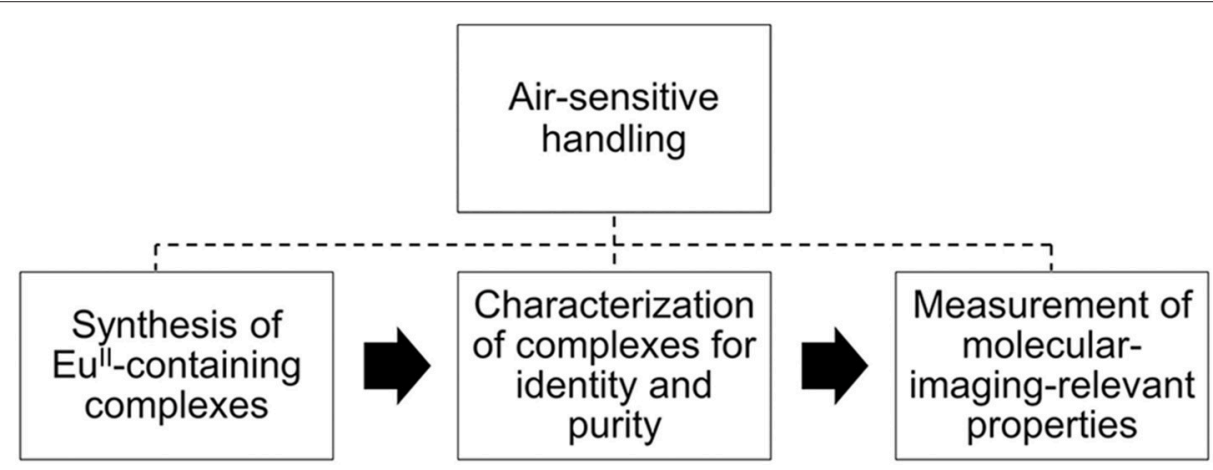

FIGURE 1 | Pathway for Eull-containing complexes that have applications in molecular imaging. 


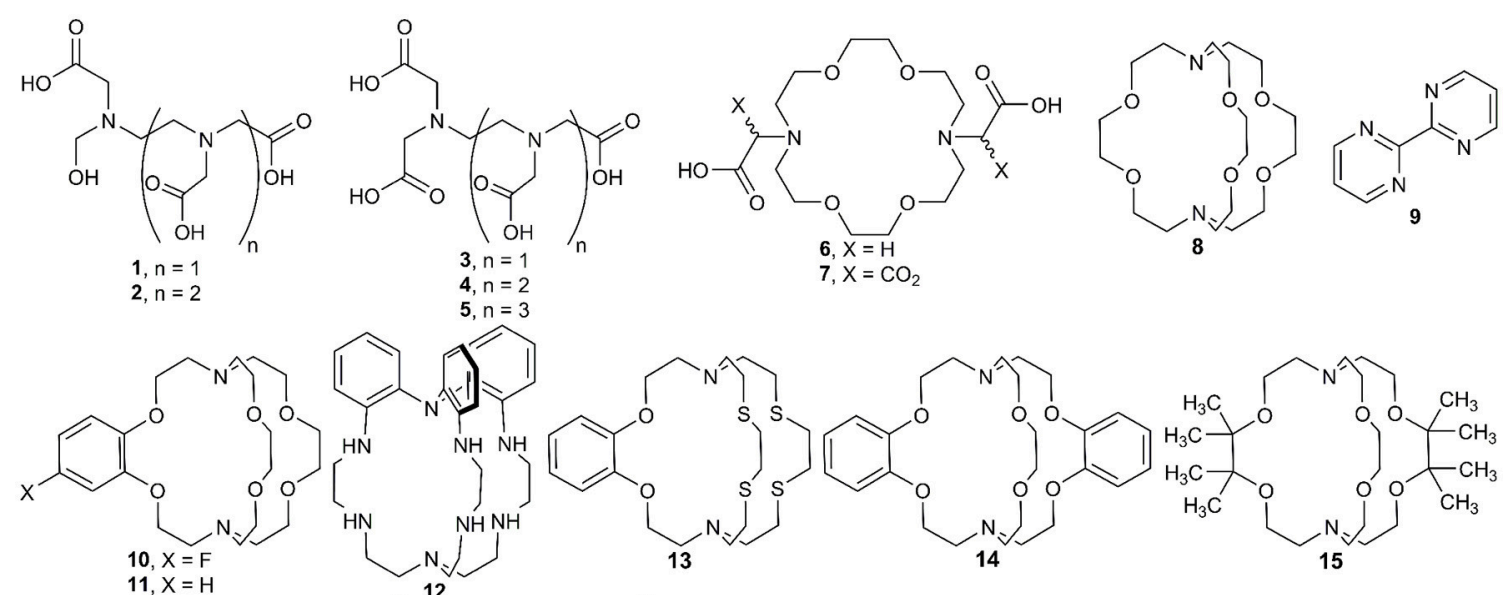<smiles>C1CNCCNCCNCCNCCNCCNCCN1</smiles><smiles>O=C(COc1ccccc1OCC(=O)N1CCOCCOCCOCC1)NCCO</smiles><smiles>O=C1CSCCSCC(=O)N2CCOCCOCCOCCOCCN1C2</smiles><smiles>c1ccc(-c2ccc(C[C@H]3COCCN4CCOCCOCCN(CCOCCOCCO4)CCO3)cc2)cc1</smiles><smiles>C1COCCN2CCOCCOCCN(C1)CCOCCOCC2</smiles><smiles>CCN1CCOCCOCCN2CCOc3ccccc3OCCN1CCO2</smiles><smiles>O=C(O)CN(CCOCCOCCN(CC(=O)O)CC(=O)O)CC(=O)O</smiles><smiles>O=C(O)CN(CCN(CC(=O)O)CC(=O)CN(CC(=O)O)C(COCc1ccccc1)C(=O)O)CC(=O)O</smiles><smiles>c1cc2nc(c1)COCCOCc1cccc(n1)COCCCOC2</smiles><smiles>O=C(O)CN1CCCN(CC(=O)O)CCN(CC(=O)O)CCC1</smiles>

22<smiles>[X]c1ccc(CNCC)cc1</smiles><smiles>[X]c1ccc(CNC(=O)O)cc1</smiles><smiles>[X]C(=O)c1cccc(CN2CCOCCOCCN(Cc3cccc(C([Y])=O)n3)CCOCCOCC2)n1</smiles>

28, $X=Y=O H$ 29, $X=Y=\mathrm{NH}_{2}$ 30, $\mathrm{X}=\mathrm{OH}, \mathrm{Y}=\mathrm{NH}_{2}$

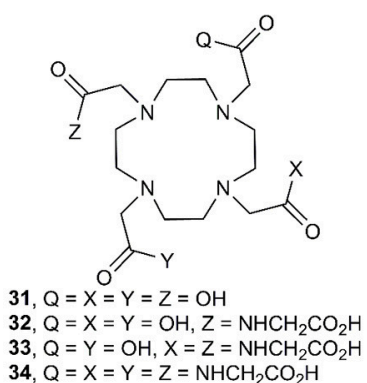

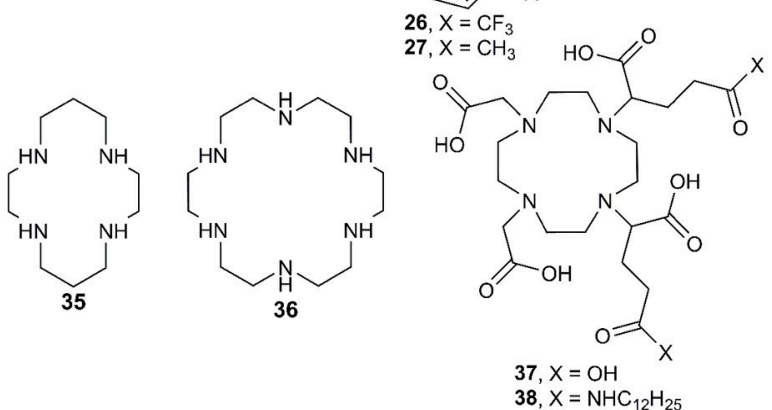<smiles>O=C(O)CN1CCNCCN(CC(=O)O)CCN(CC(=O)O)CC1</smiles>

FIGURE 2 | Ligands used with Eull and the techniques described in the synthesis section of this manuscript.

from $\mathrm{Eu}{ }^{\mathrm{III}}$, like cryptands $\mathbf{8}, \mathbf{2 0}$, and $\mathbf{2 1}$, produce the same electrochemical profiles whether starting with a mixture of $\mathrm{Eu}^{\text {III }}$ and ligand or a $\mathrm{Eu}^{\mathrm{II}}$-containing complex (Yee et al., 1980,
1983). When solubility differences exist between ligands and their corresponding complexes, such as if the ligand is not soluble but the complex is, then one must ensure complexation prior 


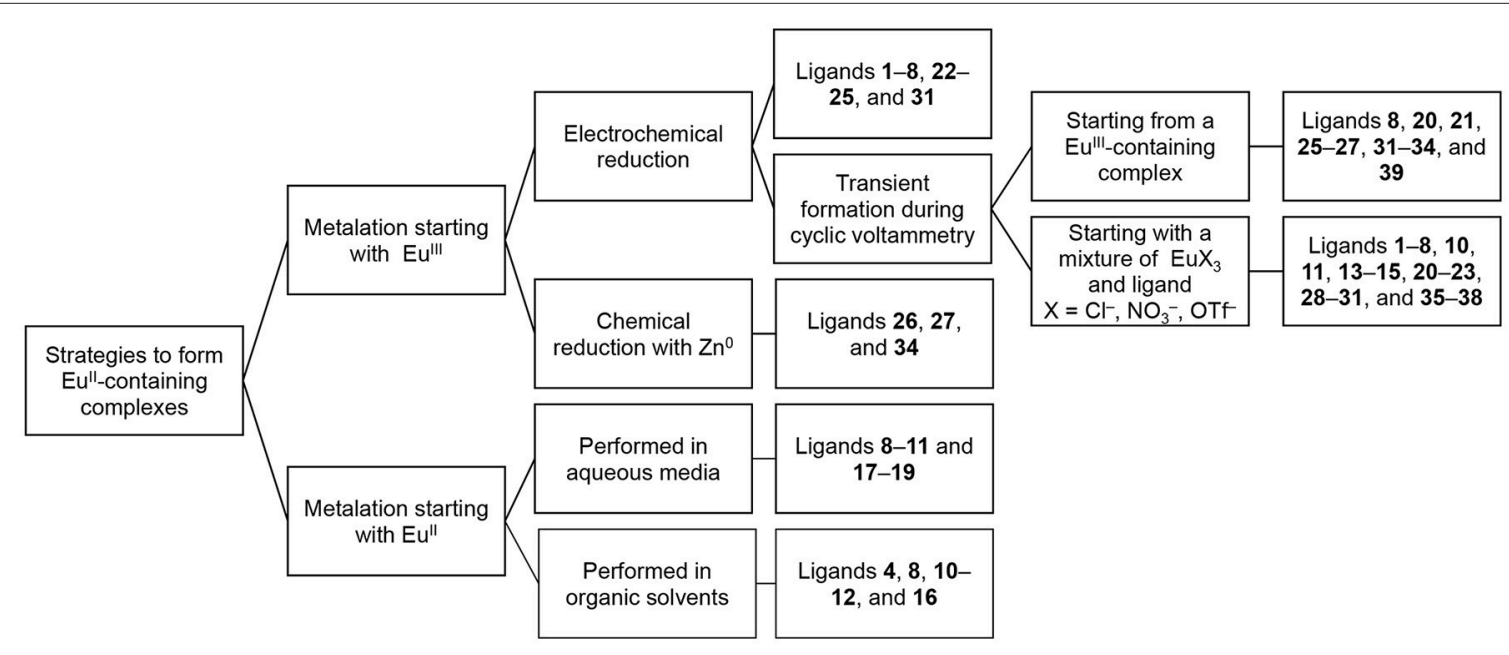

FIGURE 3 | Reported strategies to form the Eu"l-containing complexes included in this manuscript.

to $\mathrm{CV}$ analysis. If the complex is insoluble in aqueous media, then organic solvents can be employed with the caveat that the measured standard electrode potential might not be reflect the potential under aqueous conditions.

\section{Producing Eu"ll-Containing Complexes via Electrochemical Reduction of Eu ${ }^{\text {III }}$}

Beyond the transient reduction of $\mathrm{Eu}^{\mathrm{III}}$ on the surface of electrodes during cyclic voltammetry, Eu ${ }^{\mathrm{III}}$ can be reduced on an isolable scale electrochemically using bulk electrolysis in oxygen-free solvent under an atmosphere of inert gas. Reduction via bulk electrolysis involves holding a sufficiently negative potential to reduce $\mathrm{Eu}^{\mathrm{III}}$ to $\mathrm{Eu}^{\mathrm{II}}$. The electrochemical potential used to reduce a $\mathrm{Eu}^{\mathrm{III}}$-containing complex is often $0.1-0.5 \mathrm{~V}$ more negative than the $E_{1 / 2}$ of the target complex (Burai et al., 2002, 2003; Botta et al., 2003); however, the reduction potential of the ligand functional groups should be considered before selecting this technique to avoid the possibility of reducing redox-active ligands. Bulk electrolysis was used to obtain $\mathrm{Eu}^{\mathrm{II}}$ containing complexes of 1-8, 22-25, and $\mathbf{3 1}$ (Sabbatini et al., 1982, 1984; Burai et al., 2000, 2002; Christoffers and Starynowicz, 2008). In these studies, solutions containing both $\mathrm{Eu}^{\mathrm{III}}$ salts and ligands were held at the appropriate potential, typically in a two-compartment glass cell with a fritted glass separator with sparging of inert gas (Bard and Faulkner, 2000). The resulting $\mathrm{Eu}^{\mathrm{II}}$-containing complexes can be used for further analysis of molecular-imaging-relevant properties, including UV-visible and luminescence spectroscopy, relaxivity measurements, ${ }^{17} \mathrm{O}$ NMR spectroscopy, and NMRD measurements (Sabbatini et al., 1984; Burai et al., 2000, 2002; Christoffers and Starynowicz, 2008). Bulk electrolysis of a solution of metal and ligand can provide enough material to obtain crystals for X-ray diffraction: for example, bulk electrolysis of $\mathrm{Eu}^{\mathrm{III}}$ to $\mathrm{Eu}^{\mathrm{II}}$ in the presence of ligand $\mathbf{2 4}$ followed by slow evaporation or cooling under inert atmosphere resulted in crystals of $\mathrm{Eu}^{\mathrm{II}} \mathbf{2 4}$ (Christoffers and Starynowicz, 2008). Bulk electrolysis to produce isolable $\mathrm{Eu}^{\mathrm{II}}$-containing complexes is appropriate when the potential needed to reduce a $\mathrm{Eu}^{\mathrm{III}}$-containing complex to a $\mathrm{Eu}^{\mathrm{II}}$-containing complex does not overlap with the redox-activity of the ligand, when the desired $\mathrm{Eu}^{\mathrm{II}}$ salt is unavailable, or when the standard potential or $\mathrm{pH}$ of the complex in solution is incompatible with chemical reductants.

\section{Chemical Reduction of Eu'II-Containing Complexes to Form Eu"-Containing Complexes}

In addition to bulk electrolysis, chemical reductants are used to generate $\mathrm{Eu}^{\mathrm{II}}$-containing complexes. Depending on the standard potential of the $\mathrm{Eu}^{\mathrm{III}}$-containing complex to be reduced, different reducing agents will be appropriate. For example, the reduction potential of $\mathrm{Zn}\left(\mathrm{Zn}^{\mathrm{II}}+2 \mathrm{e}^{-} \rightarrow \mathrm{Zn}^{0}\right)$ is $-0.960 \mathrm{~V}$ vs $\mathrm{Ag} / \mathrm{AgCl}$ (saturated KCl) (Bard and Faulkner, 2000); therefore, complexes that have standard electrode potentials more positive than $-0.960 \mathrm{~V}$ vs $\mathrm{Ag} / \mathrm{AgCl}$ should, thermodynamically, be reduced by $\mathrm{Zn}^{0}$. Eu ${ }^{\mathrm{III}}$-containing complexes were reduced using $\mathrm{Zn}^{0}$ to form $\mathrm{Eu}^{\mathrm{II}}$ 26, Eu${ }^{\mathrm{II}} \mathbf{2 7}$, and $\mathrm{Eu}^{\mathrm{II}} \mathbf{3 4}$ (Ekanger et al., 2016a; Basal et al., 2017a,b). In these studies, the Eu ${ }^{\mathrm{III}}$-containing complexes were dissolved in water in the presence of zinc metal dust, and the $\mathrm{pH}$ was adjusted between 4 and 6.5 to expose $\mathrm{Zn}^{0}$, resulting in the reduction of $\mathrm{Eu}^{\mathrm{III}}$ to $\mathrm{Eu}^{\mathrm{II}}$. To date, only amalgamated $\mathrm{Zn}$ and $\mathrm{Zn}^{0}$ have been used to chemically reduce $\mathrm{Eu}^{\mathrm{III}}$-containing complexes to $\mathrm{Eu}^{\mathrm{II}}$-containing complexes in water (McCoy, 1935; Ekanger et al., 2016a; Basal et al., 2017a,b). However, other chemical reductants, which have been used to reduce other $\mathrm{Ln}^{\mathrm{III}}$ ions to $\mathrm{Ln}^{\mathrm{II}}$ ions (Teprovich et al., 2008; MacDonald et al., 2013; Fieser et al., 2015), could be used if the low $\mathrm{pH}$ required for the use of zinc metal is undesirable or if the standard electrode potential of the Eu-containing complex is more negative than that of $\mathrm{Zn}^{0}$.

\section{Complex Formation by Direct Mixing of Eu" Salts and Ligands}

Another technique to synthesize $\mathrm{Eu}^{\mathrm{II}}$-containing complexes is mixing $\mathrm{Eu}^{\mathrm{II}}$ halide salts with ligands. $\mathrm{Eu}^{\mathrm{II}}$ chloride, bromide, 


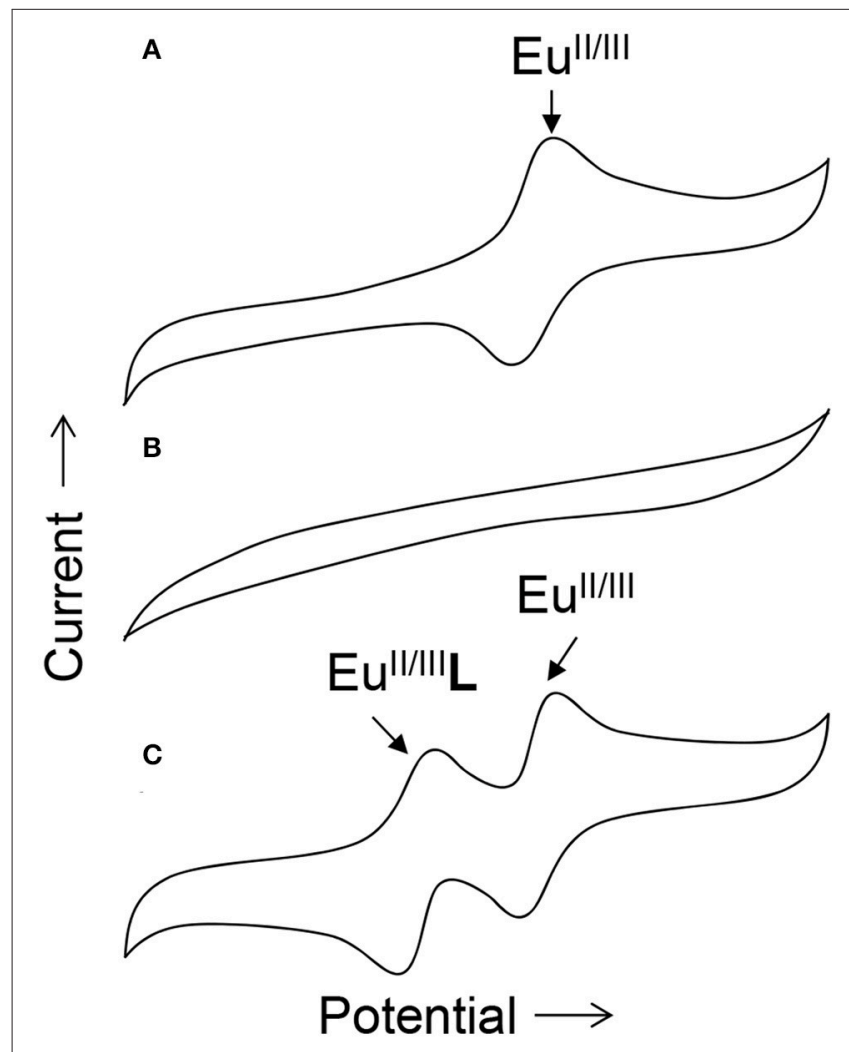

FIGURE 4 | Cartoon cyclic voltammograms of (A) a solution of Eu $u_{\text {aqua }}^{\text {IIIII }}$ water, (B) a solution of ligand $\mathbf{L}$ in water, and $(\mathbf{C})$ a solution of both Eu $\mathrm{u}_{\text {aqua }}$ and $\mathbf{L}$ in water. The new peak in $(\mathbf{C})$ relative to $(\mathbf{A})$ is indicative of the in-situ formation of the Eu-containing complex EuL.

and iodide salts are available commercially. When mixing $\mathrm{Eu}^{\mathrm{II}}$ and ligands, often a slight excess of a $\mathrm{Eu}^{\mathrm{II}}$ halide salt (1.1-1.2 equivalents) is mixed with a water-soluble ligand (1 equivalent) in water. Complexes tend to be easier to purify from an excess of $\mathrm{Eu}^{\mathrm{II}}$ relative to an excess of ligand: the addition of phosphate buffer precipitates excess $\mathrm{Eu}^{\mathrm{II}}$ from solution as phosphate salts that can be removed with a small ( 0.2 micrometer) hydrophilic filter to yield a buffered solution of $\mathrm{Eu}^{\mathrm{II}}$-containing complex (Garcia and Allen, 2012b). This technique was used to synthesize $\mathrm{Eu}^{\mathrm{II}}$-containing complexes of 8-11 and 17-19 (Zucchi et al., 2010; Garcia and Allen, 2012b; Garcia et al., 2012; Ekanger et al., 2014, 2015, 2016b, 2017; Lenora et al., 2017).

When a ligand is not water-soluble but the resulting complex is, aqueous solutions of $\mathrm{Eu}^{\mathrm{II}}$-containing complexes can be prepared by mixing $\mathrm{Eu}^{\mathrm{II}}$ salts with ligands in an organic solvent and then separating the resulting complex from the organic solvent. Purification by precipitation or crystallization results in solids that are soluble in water for imaging. For an example of purification by precipitation, $\mathrm{Eu}^{\mathrm{II}} \mathbf{1 6}$ was synthesized in tetrahydrofuran: $\mathrm{EuI}_{2}$ and $\mathbf{1 6}$ are soluble in tetrahydrofuran, but $\mathrm{Eu}^{\mathrm{II}} \mathbf{1 6}$ is not, enabling isolation of $\mathrm{Eu}^{\mathrm{II}} \mathbf{1 6}$ by precipitation (Kuda-Wedagedara et al., 2015). For an example of purification by crystallization, crystals were grown of cryptates $\mathrm{Eu}^{\mathrm{II}} \mathbf{4}, \mathrm{Eu}^{\mathrm{II}} \mathbf{8}$, $\mathrm{Eu}^{\mathrm{II}} 10, \mathrm{Eu}^{\mathrm{II}} 11, \mathrm{Eu}^{\mathrm{II}} 12$, and $\mathrm{Eu}^{\mathrm{II}} 16$ from slow evaporation of a mixture of ligand and $\mathrm{Eu}^{\mathrm{II}}$ halide in acetone, methanol, or methanol/tetrahydrofuran (Burai et al., 2000; Ekanger et al., 2015; Kuda-Wedagedara et al., 2015; Jin et al., 2016; Lenora et al., 2017).

\section{CHARACTERIZATION FOR IDENTITY AND PURITY IN AQUEOUS MEDIA}

Depending the route chosen to form $\mathrm{Eu}^{\mathrm{II}}$-containing complexes, different techniques for the characterization of identity and purity of $\mathrm{Eu}^{\mathrm{II}}$-containing complexes must be used (Figure 5). Assessment of identity of $\mathrm{Eu}^{\mathrm{II}}$-containing complexes includes evidence for the oxidation state of $\mathrm{Eu}$, coordination environment, and metal-to-ligand ratio. Assessment of the purity of $\mathrm{Eu}^{\mathrm{II}}$ containing complexes includes the detection of $\mathrm{Eu}^{\mathrm{II}}$ or $\mathrm{Eu}^{\mathrm{III}}$, ligand, reactants, or byproducts.

When $\mathrm{Eu}^{\mathrm{II}}$-containing complexes are generated in situ via cyclic voltammetry, purity with respect to excess $\mathrm{Eu}_{\text {aqua }}^{\mathrm{II}}$ can be

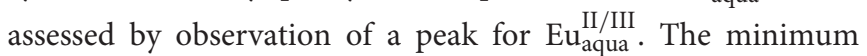
detectable concentration of europium by cyclic voltammetry, and hence the boundary of usefulness for this technique, is influenced by multiple experimental parameters including concentration of supporting electrolyte, the identity of the buffer and solvent, and choice of reference electrode (Bard and Faulkner, 2000). With these parameters in mind, minimum detectable concentrations can be determined experimentally (Harris, 2003). Unlike Eu ${ }^{\mathrm{II} / \mathrm{III}}$, if a ligand is not redox-active, cyclic voltammetry does not provide evidence for the presence of uncomplexed ligand. Therefore, the usefulness of cyclic voltammetry for detection of excess ligand is situationally dependent.

Regarding the identity of the complex that is formed during the course of cyclic voltammetry, formation of a Eu-containing complex can be validated by comparing the standard electrode potential of the new complex with the standard electrode potential of a sample of the Eu-containing complex (Tables 1, 2). For example, $\mathrm{Eu}^{\mathrm{II}}$-containing complexes of $\mathbf{8}, \mathbf{2 0}$, and 21 were synthesized and found to produce the same $E_{1 / 2}$ whether starting with a mixture of Eu ${ }^{\mathrm{III}}$ and ligand or an alreadysynthesized $\mathrm{Eu}^{\mathrm{II}}$-containing complex (Yee et al., 1980, 1983). However, the standard electrode potential is influenced by the same experimental parameters that are listed for consideration of purity using cyclic voltammetry; therefore, care must be taken to note experimental parameters when comparing standard electrode potentials.

In the case where $\mathrm{Eu}^{\mathrm{III}}$-containing complexes are reduced chemically with zinc, such as $2 \mathrm{Eu}_{2} 2 \mathrm{Cl}_{3}+\mathrm{Zn}^{0} \rightarrow 2 \mathrm{Eu}_{2} 2 \mathrm{Cl}_{2}$ $+\mathrm{ZnCl}_{2}$, a combination of spectroscopic techniques can be used to provide evidence of the oxidation state and degree of purity. For evidence that $\mathrm{Zn}{ }^{\mathrm{II}}$ was removed from solution postreduction, the concentration of $\mathrm{Zn}^{\mathrm{II}}$ (down to parts-per-billion levels) can be monitored with inductively coupled plasmamass spectrometry (Ekanger et al., 2016a). For evidence of the reduction of $\mathrm{Eu}^{\mathrm{III}}$, a lack of overlap of the excitation bands of $\mathrm{Eu}^{\mathrm{II}}$ - and $\mathrm{Eu}^{\mathrm{III}}$-containing species enables monitoring of the presence of $\mathrm{Eu}^{\mathrm{III}}$ (down to micromolar levels) by luminescence spectroscopy when excitation is performed with a $\mathrm{Eu}^{\mathrm{III}}$-specific wavelength (Ekanger et al., 2016a; Basal et al., 2017a). Evidence 


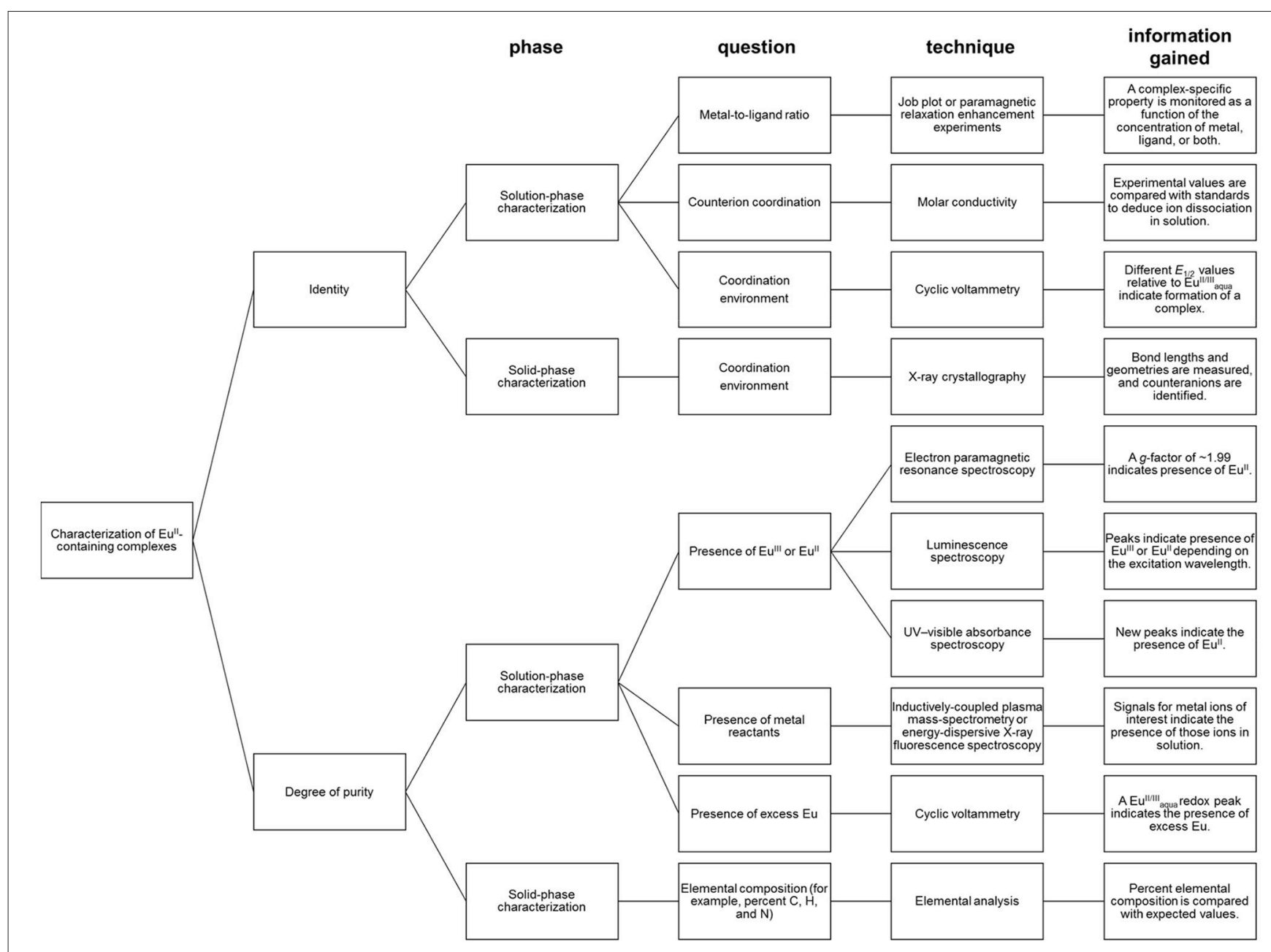

FIGURE 5 | Diagram for the characterization of Eu"l-containing complexes.

for the generation of $\mathrm{Eu}^{\mathrm{II}}$ is obtained using electron paramagnetic resonance (EPR) spectroscopy. In its ground state, $\mathrm{Eu}^{\mathrm{III}}$ has no net magnetic moment (Cullity and Graham, 2009) despite having six unpaired electrons. The magnetic moment $\left(\mu_{\mathrm{eff}}\right)$ of lanthanides is calculated using the total angular momentum $(J)$, unlike the magnetic moments of $3 \mathrm{~d}^{n}$ transition metals that take into account the number of unpaired electrons (Cotton, 2006; Layfield et al., 2015). This difference is due to the quenching of orbital angular momentum by ligands for $3 \mathrm{~d}$ orbitals but not for the shielded $4 \mathrm{f}$ orbitals. Therefore, the $\mathrm{Eu}^{\mathrm{III}}$ ground state would not be expected to be observed in EPR spectroscopy (Abragam and Bleaney, 1970). However, Eu ${ }^{\mathrm{II}}$ is paramagnetic and characterized by a signal in EPR spectroscopy with a $g$ factor of $\sim 1.99$ (Abragam and Bleaney, 1970; Caravan et al., 1999). Also, $\mathrm{Eu}^{\mathrm{II}}$-containing complexes can be colored yellow or orange and give rise to broad and relatively intense UV-visible absorptions and emissions that are distinct from the corresponding $\mathrm{Eu}^{\mathrm{III}}$ containing species (Burai et al., 2003; Kuda-Wedagedara et al., 2015; Ekanger et al., 2016a). For example, a combination of spectroscopic techniques were used to monitor the formation of
$\mathrm{Eu}^{\mathrm{II}}$-containing complexes Eu22, Eu26, and Eu34 (Ekanger et al., 2016a; Basal et al., 2017a).

In the case where the formation of a complex was achieved by mixing $\mathrm{EuCl}_{2}$ with ligands, evidence of 1:1 complex formation in solution was determined by measuring the change in relaxivity as a function of $\mathrm{Eu}^{\mathrm{II}}$-to-ligand ratio, a technique known as proton relaxation enhancement (Lauffer, 1987; Lenora et al., 2017). Another solution-phase technique to monitor complex formation is a Job plot where both ligand and metal ratios are varied, and a unique property of the complex, such as a complex-specific emission, is monitored (Renny et al., 2013; Kuda-Wedagedara et al., 2015). The choice of spectral feature to monitor in a Job plot is complex-dependent. Typically, $\mathrm{Eu}^{\mathrm{II}}$ based emission is largely quenched in aqueous media due to the abundance of $\mathrm{OH}$ oscillators (Jiang et al., 1998); therefore, luminescence spectroscopy is not suitable to characterize the formation of every $\mathrm{Eu}^{\mathrm{II}}$-containing complex. Other features to monitor as a function of metal-to-ligand ratio include complexspecific absorbance peaks, relaxivity, or cyclic voltammetry peaks. 
TABLE 1 | Midpoint potentials of Eull/III -containing complexes more negative than aqua ions.

\begin{tabular}{|c|c|c|c|c|c|}
\hline Ligand & $E_{1 / 2}(\mathrm{~V})^{[\mathrm{a}]}$ & $E_{1 / 2}(\mathrm{~V})$ & $\begin{array}{l}\text { Reference } \\
\text { electrode }\end{array}$ & $\mathrm{pH}$ & References \\
\hline 5 & -1.417 & -1.373 & $\begin{array}{l}\text { saturated } \\
\text { calomel }\end{array}$ & 4 & Botta et al., 2003 \\
\hline 4 & -1.386 & -1.342 & $\begin{array}{l}\text { saturated } \\
\text { calomel }\end{array}$ & 4 & Botta et al., 2003 \\
\hline 23 & -1.375 & -1.331 & $\begin{array}{l}\text { saturated } \\
\text { calomel }\end{array}$ & 4 & Botta et al., 2003 \\
\hline 4 & -1.356 & -1.356 & $\mathrm{Ag} / \mathrm{AgCl}$ & 6.5 & Gál et al., 2013 \\
\hline 2 & -1.356 & -1.312 & $\begin{array}{l}\text { saturated } \\
\text { calomel }\end{array}$ & 4 & Botta et al., 2003 \\
\hline 4 & -1.35 & -1.35 & $\mathrm{Ag} / \mathrm{AgCl}$ & $\mathrm{nr}[\mathrm{b}]$ & Burai et al., 2000 \\
\hline 38 & -1.331 & -1.331 & $\mathrm{Ag} / \mathrm{AgCl}$ & 6.5 & Gál et al., 2013 \\
\hline 37 & -1.291 & -1.291 & $\mathrm{Ag} / \mathrm{AgCl}$ & 6.5 & Gál et al., 2013 \\
\hline 31 & -1.241 & -1.241 & $\mathrm{Ag} / \mathrm{AgCl}$ & 6.5 & Gál et al., 2013 \\
\hline 39 & -1.18 & -1.18 & $\mathrm{Ag} / \mathrm{AgCl}$ & 7 & Vanek et al., 2016 \\
\hline 22 & -1.164 & -1.120 & $\begin{array}{l}\text { saturated } \\
\text { calomel }\end{array}$ & 4 & Botta et al., 2003 \\
\hline 3 & -1.153 & -1.109 & $\begin{array}{l}\text { saturated } \\
\text { calomel }\end{array}$ & 4 & Botta et al., 2003 \\
\hline 31 & -1.135 & -1.135 & $\mathrm{Ag} / \mathrm{AgCl}$ & $\mathrm{nr}[\mathrm{b}]$ & Burai et al., 2003 \\
\hline 1 & -1.125 & -1.081 & $\begin{array}{l}\text { Saturated } \\
\text { calomel }\end{array}$ & 4 & Botta et al., 2003 \\
\hline 32 & -1.1105 & -1.1105 & $\mathrm{Ag} / \mathrm{AgCl}$ & 7 & Burnett et al., 2017 \\
\hline 33 & -1.0680 & -1.0680 & $\mathrm{Ag} / \mathrm{AgCl}$ & 7 & Burnett et al., 2017 \\
\hline 36 & -1.052 & -1.052 & $\mathrm{Ag} / \mathrm{AgCl}$ & 6.5 & Gál et al., 2013 \\
\hline 25 & -0.996 & -0.996 & $\mathrm{Ag} / \mathrm{AgCl}$ & $n r^{[b]}$ & Burai et al., 2003 \\
\hline 34 & -0.9710 & -0.9710 & $\mathrm{Ag} / \mathrm{AgCl}$ & 7 & Burnett et al., 2017 \\
\hline 6 & -0.92 & -0.92 & $\mathrm{Ag} / \mathrm{AgCl}$ & $\mathrm{nr}[\mathrm{b}]$ & Burai et al., 2000 \\
\hline 34 & -0.903 & -0.903 & $\mathrm{Ag} / \mathrm{AgCl}$ & 7 & Ekanger et al., 2016a \\
\hline 34 & -0.879 & -0.879 & $\mathrm{Ag} / \mathrm{AgCl}$ & 4 & Ekanger et al., 2016a \\
\hline 7 & -0.82 & -0.82 & $\mathrm{Ag} / \mathrm{AgCl}$ & $\mathrm{nr}[\mathrm{b}]$ & Burai et al., 2000 \\
\hline 35 & -0.817 & -0.817 & $\mathrm{Ag} / \mathrm{AgCl}$ & 6.5 & Gál et al., 2013 \\
\hline 28 & -0.753 & -0.753 & $\mathrm{Ag} / \mathrm{AgCl}$ & 7 & $\begin{array}{l}\text { Regueiro-Figueroa } \\
\text { et al., } 2015\end{array}$ \\
\hline 26 & -0.727 & -0.727 & $\mathrm{Ag} / \mathrm{AgCl}$ & $\mathrm{na}^{[\mathrm{c}]}$ & Basal et al., 2017a \\
\hline 27 & -0.720 & -0.720 & $\mathrm{Ag} / \mathrm{AgCl}$ & $\mathrm{na}^{[\mathrm{c}]}$ & Basal et al., 2017a \\
\hline
\end{tabular}

${ }^{[a]}$ Converted to $\mathrm{V}$ vs. $\mathrm{Ag} / \mathrm{AgCl}$ by subtracting $0.044 \mathrm{~V}$ from the saturated calomel values (Bard and Faulkner, 2000); ${ }^{[b]}$ nr, not reported; ${ }^{[c]}$ na, not applicable, solvent is dimethylformamide.

In the case where single crystals of a Eu ${ }^{\mathrm{II}}$-containing complex are obtained, X-ray diffraction combined with elemental analysis provides information regarding identity and purity. X-ray diffraction provides information about the oxidation state and coordination environment of the $\mathrm{Eu}^{\mathrm{II}}$ ion in the solid state, including bond distances and number and identity of counter ions (Zucchi et al., 2010; Ekanger et al., 2015; Kuda-Wedagedara et al., 2015; Jin et al., 2016; Basal et al., 2017a; Lenora et al., 2017). Elemental analysis provides information about elemental composition as an indication of purity. However, it is important to note that for molecular-imaging applications, solution-phase characterization is often more important than solid-phase analysis of solids because solid-state properties do not necessarily
TABLE 2 | Midpoint potentials of Eu ${ }^{I I / I I I}$-containing aqua complexes and complexes more positive than aqua ions.

\begin{tabular}{|c|c|c|c|c|c|}
\hline Ligand & $E_{1 / 2}(\mathrm{~V})^{[\mathrm{a}]}$ & $E_{1 / 2}(\mathrm{~V})$ & $\begin{array}{l}\text { Reference } \\
\text { electrode }\end{array}$ & $\mathrm{pH}$ & References \\
\hline aqua & -0.67 & -0.67 & $\mathrm{Ag} / \mathrm{AgCl}$ & 6.5 & Gál et al., 2013 \\
\hline aqua & -0.668 & -0.624 & $\begin{array}{l}\text { saturated } \\
\text { calomel }\end{array}$ & 4 & Botta et al., 2003 \\
\hline aqua & -0.664 & -0.620 & $\begin{array}{l}\text { saturated } \\
\text { calomel }\end{array}$ & 3 & Yee et al., 1979 \\
\hline aqua & -0.648 & -0.648 & $\mathrm{Ag} / \mathrm{AgCl}$ & $\mathrm{na}^{[\mathrm{d}]}$ & ] Basal et al., 2017a \\
\hline aqua & -0.6365 & -0.6365 & $\mathrm{Ag} / \mathrm{AgCl}$ & 7 & Burnett et al., 2017 \\
\hline aqua & -0.63 & -0.63 & $\mathrm{Ag} / \mathrm{AgCl}$ & $\mathrm{nr}[\mathrm{e}]$ & Burai et al., 2000 \\
\hline 30 & -0.61 & -0.61 & $\mathrm{Ag} / \mathrm{AgCl}$ & 7 & $\begin{array}{l}\text { Regueiro-Figueroa } \\
\text { et al., } 2015\end{array}$ \\
\hline aqua & -0.585 & -0.585 & $\mathrm{Ag} / \mathrm{AgCl}$ & $\mathrm{nr}[\mathrm{e}]$ & Burai et al., 2003 \\
\hline aqua & -0.554 & -0.554 & $\mathrm{Ag} / \mathrm{AgCl}$ & 2.08 & $\begin{array}{l}\text { Anderson and } \\
\text { Macero, } 1963\end{array}$ \\
\hline aqua & -0.549 & $-0.7645^{[b]}$ & $\mathrm{Fc}_{\mathrm{CO}}+[\mathrm{c}]$ & 7.5 & Gamage et al., 2010 \\
\hline 20 & -0.479 & -0.435 & $\begin{array}{l}\text { saturated } \\
\text { calomel }\end{array}$ & $2-7$ & Yee et al., 1980 \\
\hline 29 & -0.453 & -0.453 & $\mathrm{Ag} / \mathrm{AgCl}$ & 7 & $\begin{array}{l}\text { Regueiro-Figueroa } \\
\text { et al., } 2015\end{array}$ \\
\hline 21 & -0.41 & -0.37 & $\begin{array}{l}\text { saturated } \\
\text { calomel }\end{array}$ & $\mathrm{nr}[\mathrm{e}]$ & Yee et al., 1980 \\
\hline 8 & -0.259 & -0.215 & $\begin{array}{l}\text { saturated } \\
\text { calomel }\end{array}$ & $n r^{[e]}$ & Yee et al., 1980 \\
\hline 8 & -0.141 & $-0.3669^{[b]}$ & $\left.\mathrm{Fc} / \mathrm{FC}^{+}+\mathrm{c}\right]$ & 7.5 & Gamage et al., 2010 \\
\hline$\left[\mathrm{P}_{5} \mathrm{~W}_{30} \mathrm{O}_{110}\right]^{15-}$ & 0.11 & 0.11 & $\mathrm{Ag} / \mathrm{AgCl}$ & 0 & $\begin{array}{l}\text { Antonio and } \\
\text { Soderholm, } 1996\end{array}$ \\
\hline 14 & -0.100 & $-0.2996^{[b]}$ & $\mathrm{Fc}_{\mathrm{C}} \mathrm{FC}^{+[\mathrm{c}]}$ & 7.5 & Gamage et al., 2010 \\
\hline 11 & -0.068 & $-0.2769^{[b]}$ & $\mathrm{FC}_{\mathrm{FC}}+[\mathrm{c}]$ & 7.5 & Gamage et al., 2010 \\
\hline 10 & 0.016 & $-0.2324^{[b]}$ & $\mathrm{FC}_{\mathrm{FC}}+[\mathrm{c}]$ & 7.5 & Gamage et al., 2010 \\
\hline 13 & 0.083 & $-0.2123^{[b]}$ & $\left.\mathrm{Fc} / \mathrm{FC}^{+}+\mathrm{c}\right]$ & 7.5 & Gamage et al., 2010 \\
\hline 16 & 0.13 & 0.13 & $\mathrm{Ag} / \mathrm{AgCl}$ & 9.7 & $\begin{array}{l}\text { Kuda-Wedagedara } \\
\text { et al., } 2015\end{array}$ \\
\hline
\end{tabular}

${ }^{[a]}$ Converted to $\mathrm{V}$ vs. Ag/AgCl by subtracting $0.044 \mathrm{~V}$ from the saturated calomel values (Bard and Faulkner, 2000) or by adding $\left|E_{p a(A g / A g C l)}-E_{\text {pa(ferrocene/ferrocenium) })}\right|$ to the reported $E_{1 / 2}$ values vs. ferrocene/ferrocenium (Gamage et al., 2010); $\left[{ }^{[b]}\right.$ average of the anodic and cathodic peak potentials; ${ }^{[c]} \mathrm{FC}_{\mathrm{C}} / \mathrm{FC}^{+}$, ferrocene/ferrocenium; ${ }^{[d]}$ na, not applicable, solvent is dimethylformamide; ${ }^{[e]} \mathrm{nr}$, not reported.

reflect solution-phase behavior or coordination environment. For example, $\mathrm{Eu}^{\mathrm{II}}$-containing complexes Eu10, Eu11, and Eu16, crystallize with one chloride counteranion bound to $\mathrm{Eu}^{\mathrm{II}}$. In the case of Eu16, solution-phase characterization suggests that the counteranion remains coordinated to $\mathrm{Eu}^{\mathrm{II}}$ in solution (KudaWedagedara et al., 2015); however, for Eu10 and Eu11, molarconductivity data suggests that counteranions dissociate in solution (Ekanger et al., 2015; Lenora et al., 2017).

\section{HANDLING Eu"-CONTAINING SAMPLES TO PREVENT OXIDATION}

Preventing $\mathrm{Eu}^{\mathrm{II}}$-containing complexes from oxidizing over the course of analyses is critical for the collection of accurate data: $\mathrm{Eu}^{\mathrm{III}}$ and $\mathrm{Eu}^{\mathrm{II}}$ have different properties, and misinterpretation 
of experimental results can occur if care is not taken to prevent unintentional oxidation of $\mathrm{Eu}^{\mathrm{II}}$. Rigorous techniques must be used in the synthesis and handling of $\mathrm{Eu}^{\mathrm{II}}$-containing complexes. This section describes apparatuses and techniques that were successfully used to study Eu ${ }^{\mathrm{II}}$-containing complexes (Figures 6, 7).

Cyclic voltammetry or bulk electrolysis performed either inside or outside of a glovebox should use solvents that have been degassed (under reduced pressure, for example, on a Schlenck line) or well-sparged ( $\geq 5$ min of vigorous bubbling with an inert gas for volumes of $\sim 3 \mathrm{~mL}$ in a capped vessel that contains a vent needle). To ensure that there is no detectable dissolved oxygen in solution, cyclic voltammetry of degassed solvents should not show peaks for $\mathrm{O}_{2}$ (Green, 2018). If outside of a glovebox, the inert-gas source should be retracted to the head-space of the vessel once sparging is complete prior to cyclic voltammetry or bulk electrolysis. Inside the glovebox, there is no need for an inert gas line in the headspace because the atmosphere is $\mathrm{O}_{2}$-free. If outside of a glovebox, transfer of solutions of $\mathrm{Eu}^{\mathrm{II}}$ from bulk electrolysis for crystal growth or other analyses must be performed using air-free techniques (Shriver and Drezdzon, 1986).

For other routes to synthesize and handle $\mathrm{Eu}^{\mathrm{II}}$-containing complexes in aqueous media, air-free handling is achieved using Shlenck techniques, a wet (water allowed but no molecular oxygen) glovebox, or a combination of both. During the synthesis of $\mathrm{Eu}^{\mathrm{II}}$-containing complexes in a glovebox, the glovebox atmosphere must not be contaminated with oxygen. Either a commercial oxygen sensor or chemical indicator can be used to monitor the atmosphere. One suitable chemical indicator for this purpose is dicyclopentadienyltitanium(IV) dichloride ( $\mathrm{Ti}^{\mathrm{IV}} \mathrm{Cp}_{2} \mathrm{Cl}_{2}$ ) (Burgmayer, 1998). When the titanium metallocene is dissolved in acetonitrile in the presence of zinc metal, a deep blue solution is obtained. An aliquot of this solution

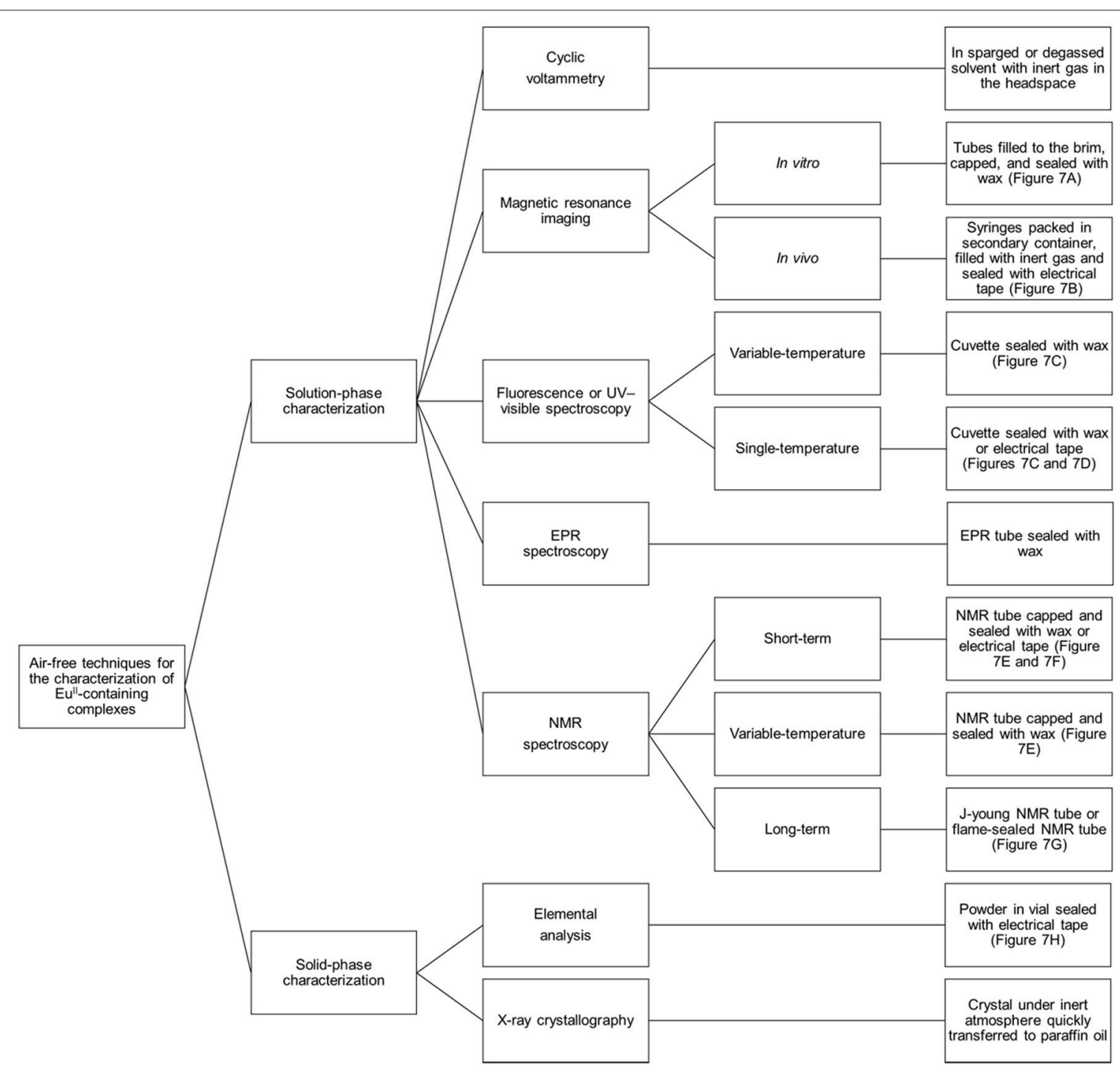

FIGURE 6 | Diagram describing techniques that can be used to analyze Eull-containing complexes with air-free conditions. 
is filtered through celite or a hydrophilic filter and diluted with acetonitrile to yield a diffuse, blue solution caused by the presence of $\mathrm{Ti}^{\mathrm{III}} \mathrm{Cp}_{2}\left(\mathrm{NCCH}_{3}\right)_{2}$. If the solution remains blue upon evaporation, $\mathrm{Ti}^{\mathrm{III}} \mathrm{Cp}_{2}\left(\mathrm{NCCH}_{3}\right)_{2}$ is unoxidized, indicating that the atmosphere is good $\left(<5 \mathrm{ppm} \mathrm{O}_{2}\right.$ ) (Shriver and Drezdzon, 1986). A color change to green is caused by formation of a dimeric species or some oxidation of $\mathrm{Ti}^{\mathrm{III}}$ to $\mathrm{Ti}^{\mathrm{IV}}$. A color change to yellow is indicative of near-complete oxidation to $\mathrm{Ti}^{\mathrm{IV}} \mathrm{Cp}_{2}\left(\mathrm{NCCH}_{3}\right)_{2}$. Either green or yellow suggests a bad atmosphere with respect to $\mathrm{O}_{2}$, and steps to address the quality of the atmosphere should be taken prior to working with $\mathrm{Eu}^{\mathrm{II}}$. If the indicator persists as green or yellow after refreshing the glovebox atmosphere by purging the glovebox with inert gas, then the oxygen-removing catalyst should be replaced or regenerated. Ideally, the atmosphere of a wet glovebox should be checked at least daily, and the atmosphere should be purged with inert gas before and after each use. All liquids to be used in a wet glovebox should be rigorously degassed before transport into the glovebox. Solids to be brought into a glovebox can be placed in an open vial and brought into the antechamber if the solids do not sublime at the temperature and pressure of the glovebox antechamber. To prevent loss of solid from bumping or the vial accidentally tipping, the top of the vial can be covered with tissue that is secured with a rubber band (Figure 7I). If solids sublime at the temperature and pressure of the antechamber, then the solids should be placed under an inert atmosphere in a sealed container prior to being brought into the glovebox.

Solution-phase characterization of $\mathrm{Eu}^{\mathrm{II}}$-containing samples, including NMR spectroscopy, MRI, and fluorescence or UVvisible absorbance spectroscopy, requires that samples be sealed to prevent oxygen contamination that would interfere with the integrity of the results. For NMR spectroscopy, J-young NMR tubes with Teflon seals or flame-sealed NMR tubes are appropriate for long term studies (Figure 7G). Alternatively, NMR tubes capped with a plastic cap and sealed with paraffin wax or electrical tape suffice for studies that last a few hours (Figures 7E,F and Video S1). For samples that must be shipped, samples can be loaded into NMR tubes that are subsequently flame-sealed (Lenora et al., 2017). For MRI, tubes (for example, glass vials that have a $400 \mu \mathrm{L}$ capacity) can be filled to the brim with solution (to avoid bubbles), capped, dipped in wax, and loaded into an apparatus that is then covered in paraffin wax (Figure 7A) (Garcia and Allen, 2012b; Garcia et al., 2012; Basal et al., 2017a,b). For in-vivo injections, syringes with rubber-tip
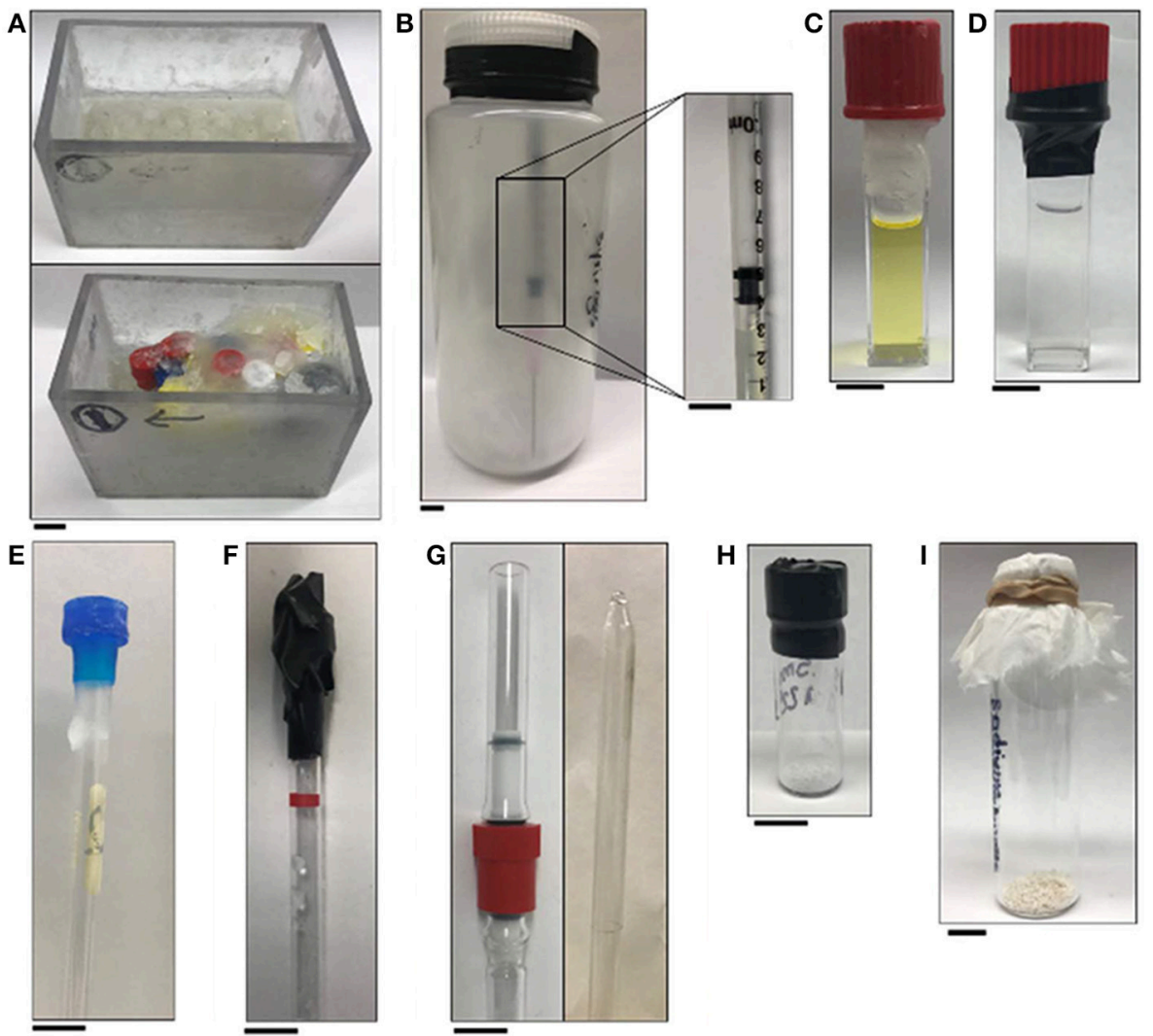

FIGURE 7 | Pictures of apparatuses included in the handling section of this manuscript: (A) empty tube holder (top) and tube holder with tubes that are covered in wax (bottom); (B) jar sealed with electrical tape that contains glass wool and syringes of Eull -containing complexes packed under an inert atmosphere and (inset) a plastic $1 \mathrm{~mL}$ syringe with a rubber tip on the plunger that contains a solution of a Eull-containing complex; (C) wax-sealed cuvette; (D) electrical-tape-sealed cuvette; (E) wax-sealed NMR tube; (F) electrical-tape-sealed NMR tube; (G) J-young NMR tube (left) and flame-sealed NMR tube (right); (H) electrical-tape-sealed vial containing a solid sample; and (I) glass vial that contains solid sample covered with a tissue that is secured with a rubber band. All scale bars represent $1 \mathrm{~cm}$. 
plungers can be loaded with sample, packaged in a bottle that is under an atmosphere of $\mathrm{N}_{2}$ or Ar, and sealed with electrical tape (Figure 7B; Basal et al., 2017a). Packed this way, the integrity of samples is sufficient for shipping with glass wool included in the bottle to minimize vibrations during shipping. For samples in cuvettes (for example, samples for emission or absorbance spectroscopy that must be removed from the glovebox), quartz cuvettes with Teflon caps can be sealed with paraffin wax (Figure 7C) or electrical tape (Figure 7D) (Kuda-Wedagedara et al., 2015; Ekanger et al., 2016a; Jin et al., 2016; Basal et al., 2017a). For samples that will undergo temperature changes (heating or cooling), we have observed that paraffin wax is more reliable than electrical tape.

To ensure that a technique or apparatus successfully seals $\mathrm{Eu}^{\mathrm{II}}$ from air over the course of an experiment, the relaxivity, UV-visible absorption, or luminescence spectra of the Eu ${ }^{\mathrm{II}}$ containing complex can be measured immediately after sample preparation and after the analyses are complete, if the analyses are nondestructive. Another way to assess the air-free environment and handling of a $\mathrm{Eu}^{\mathrm{II}}$-containing sample is to measure a spectral feature of the Eu ${ }^{\mathrm{II}}$-containing complex as a function of time at different concentrations of europium. Time-dependent measurements can reveal the presence of oxidizing impurities (Burai et al., 2002). For example, the oxidation half-life $\left(t_{1 / 2}\right)$, which is the time at which half of the complex has oxidized, was measured for Eu6 by monitoring the intensity of a complexspecific UV-visible absorbance peak as a function of time (Burai et al., 2002). For a $5 \mathrm{mM}$ solution of Eu6, the $t_{1 / 2}$ was found to be 10 days. However, $t_{1 / 2}$ increased as a function of concentration of europium (>1 month for Eu6 at $100 \mathrm{mM}$ ), suggesting that the $t_{1 / 2}$ reported at $5 \mathrm{mM}$ was influenced by the presence of oxidizing impurities such as $\mathrm{O}_{2}$. Oxygen can be avoided using the techniques described in this section.

If a Eu ${ }^{\mathrm{II}}$-containing sample cannot be monitored to check the effectiveness of an air-free technique, then another way to assess if an apparatus is sealed from air is to monitor the color change of a solution of $\mathrm{Ti}^{\mathrm{III}} \mathrm{Cp}_{2} \mathrm{Cl}_{2}$ sealed in parallel to the sample to

\section{REFERENCES}

Abragam, A., and Bleaney, B. (1970). Electron Paramagnetic Resonance of Transition Ions. Belfast: Oxford University Press.

Allen, M. J. (2016). Aqueous lanthanide chemistry in asymmetric catalysis and magnetic resonance imaging. Synlett 27, 1310-1317. doi: 10.1055/s-0035-1561363

Anderson, L. B., and Macero, D. J. (1963). The formal reduction potential of the europium(III)-europium(II) system. J. Phys. Chem. 67, 1942-1942. doi: 10.1021/j100803a520

Angelovski, G. (2016). What we can really do with bioresponsive MRI contrast agents. Angew. Chem. Int. Ed. 55, 7038-7046. doi: 10.1002/anie.201510956

Antonio, M. R., and Soderholm, L. (1996). Redox behavior of europium in the Preyssler heteropolyanion $\left[\mathrm{EuP}_{5} \mathrm{~W}_{30} \mathrm{O}_{110}\right]^{12-}$. J. Clust. Sci. 7, 585-591. doi: 10.1007/BF01165803

Bard, A. J., and Faulkner, L. R. (2000). Electrochemical Methods: Fundamentals and Applications, 2nd Edn. New York, NY: John Wiley \& Sons, Inc.

Barnham, K. J., Masters, C. L., and Bush, A. I. (2004). Neurodegenerative diseases and oxidative stress. Nat. Rev. Drug Discov. 3, 205-214. doi: 10.1038/nr d 1330 be measured (Burgmayer, 1998). The use of $\mathrm{Ti}^{\mathrm{III}} \mathrm{Cp}_{2} \mathrm{Cl}_{2}$ as an indicator provides information regarding the technique used to seal the solution from air. However, a limitation of this method is that it does not provide direct information about the $\mathrm{Eu}^{\mathrm{II}}$ containing complex being analyzed.

\section{CONCLUSIONS AND OUTLOOK}

The unique and tuneable properties of $\mathrm{Eu}^{\mathrm{II}}$ make $\mathrm{Eu}^{\mathrm{II}}$-containing complexes promising molecular imaging agents. The synthesis, characterization, and handling of $\mathrm{Eu}^{\mathrm{II}}$ require care with respect to the use of air-free techniques and characterization of oxidation states because $\mathrm{Eu}^{\mathrm{II}}$ and $\mathrm{Eu}^{\mathrm{III}}$ have different molecular imaging properties that confound results if the ions are inadvertently comingled within a sample. We expect that the techniques described in this review will guide the future synthesis, characterization, and handling of $\mathrm{Eu}^{\mathrm{II}}$-containing complexes for molecular imaging.

\section{AUTHOR CONTRIBUTIONS}

LB and MA: Contributed to the manuscript and approved the final version.

\section{ACKNOWLEDGMENTS}

MA gratefully acknowledges support from the National Institutes of Health (R01EB013663), and LB was supported by a Rumble fellowship from Wayne State University.

\section{SUPPLEMENTARY MATERIAL}

The Supplementary Material for this article can be found online at: https://www.frontiersin.org/articles/10.3389/fchem. 2018.00065/full\#supplementary-material

Video S1 | Video demonstration of the sealing of an NMR sample with paraffin wax.

Basal, L. A., Bailey, M. D., Romero, J., Ali, M. M., Kurenbekova, L., Yustein, J., et al. (2017a). Fluorinated $\mathrm{Eu}^{\mathrm{II}}$-based multimodal contrast agent for temperatureand redox-responsive magnetic resonance imaging. Chem. Sci. 8, 8356-8350. doi: 10.1039/C7SC03142D

Basal, L. A., Yan, Y., Shen, Y., Haacke, E. M., Mehrmohammadi, M., and Allen, M. J. (2017b). Oxidation-responsive, Eu ${ }^{\mathrm{II} / \mathrm{III}}$-based, multimodal contrast agent for magnetic resonance and photoacoustic imaging. ACS Omega 2, 800-805. doi: 10.1021/acsomega.6b00514

Bochkarev, M. N. (2004). Molecular compounds of "new" divalent lanthanides. Coord. Chem. Rev. 248, 835-851. doi: 10.1016/j.ccr.2004.04.004

Botta, M., Ravera, M., Barge, A., Bottaro, M., and Osella, D. (2003). Relationship between ligand structure and electrochemical and relaxometric properties of acyclic poly(aminocarboxylate) complexes of Eu(II). Dalton Trans. 1628-1633. doi: 10.1039/b211533f

Bottrill, M., Kwok, L., and Long, N. J. (2006). Lanthanides in magnetic resonance imaging. Chem. Soc. Rev. 35, 557-571. doi: 10.1039/b516376p

Burai, L., Scopelliti, R., and Tóth, É. (2002). Eu${ }^{\mathrm{II}}$-cryptate with optimal water exchange and electronic relaxation: a synthon for potential $\mathrm{pO}_{2}$ responsive macromolecular MRI contrast agents. Chem. Commun. 2366-2367. doi: 10.1039/B206709A 
Burai, L., Tóth, É., Moreau, G., Sour, A., Scopelliti, R., and Merbach, A. E. (2003). Novel macrocyclic Eu ${ }^{\mathrm{II}}$ complexes: fast water exchange related to an extreme $\mathrm{M}-\mathrm{O}_{\text {water }}$ distance. Chem Eur. J. 9, 1394-1404. doi: 10.1002/chem.2003 90159

Burai, L., Tóth, E., Seibig, S., Scopelliti, R., and Merbach, A. E. (2000). Solution and solid-state characterization of $\mathrm{Eu}^{\mathrm{II}}$ chelates: a possible route towards redox responsive MRI contrast agents. Chemistry 6, 3761-3770. doi: 10.1002/15213765(20001016)6:20<3761::AID-CHEM3761>3.0.CO;2-6

Burgmayer, S. J. N. (1998). Use of a titanium metallocene as a colorimetric indicator for learning inert atmosphere techniques. J. Chem. Ed. 75, 460-460. doi: $10.1021 /$ ed075p460

Burnett, M. E., Adebesin, B., Funk, A. M., Kovacs, Z., Sherry, A. D., Ekanger, L. A., et al. (2017). Electrochemical investigation of $\mathrm{Eu}^{3+/ 2+}$ redox couple in complexes with variable numbers of glycinamide and acetate pendant arms. Eur. J. Inorg. Chem. 2017, 5001-5005. doi: 10.1002/ejic.201701070

Caravan, P., Tóth, É., Rockenbauer, A., and Merbach, A. E. (1999). Nuclear and electronic relaxation $\mathrm{Eu}_{(\mathrm{aq})}^{2+}$ : an extremely labile aqua ion. J. Am. Chem. Soc. 121, 10403-10409. doi: 10.1021/ja992264v

Christoffers, J., and Starynowicz, P. (2008). A europium(II) complex with bispyridino-18-crown-6. Polydron 27, 2688-2692. doi: 10.1016/j.poly.2008.05.028

Corbin, B. A., Hovey, J. L., Thapa, B., Schlegel, H. B., and Allen, M. J. (2018). Luminescence differences between two complexes of divalent europium. J. Organomet. Chem. 857, 88-93. doi: 10.1016/j.jorganchem.2017.09.007

Cotton, S. (2006). Lanthanide and Actinide Chemistry. Chichester: John Wiley \& Sons Ltd.

Cullity, B. D., and Graham, C. D. (2009). Introduction to Magnetic Materials, 2nd Edn. Hoboken, NJ: John Wiley \& Sons, Inc.

Dorenbos, P. (2003). $\mathrm{f} \rightarrow \mathrm{d}$ transition energies of divalent lanthanides in inorganic compounds. J. Phys. Condens. Matter 15, 575-594. doi: 10.1088/0953-8984/15/3/322

Edelmann, F. T. (2016). Lanthanides and actinides: annual survey of their organometallic chemistry covering the year 2015. Coord. Chem. Rev. 318, 29-130. doi: 10.1016/j.ccr.2016.04.001

Ekanger, L. A., Ali, M. M., and Allen, M. J. (2014). Oxidation-responsive Eu ${ }^{2+/ 3+}$. liposomal contrast agent for dual-mode magnetic resonance imaging. Chem. Commun. 50, 14835-14838. doi: 10.1039/C4CC07027E

Ekanger, L. A., and Allen, M. J. (2015). Overcoming the concentration-dependence of responsive probes for magnetic resonance imaging. Metallomics 7, 405-421. doi: 10.1039/C4MT00289J

Ekanger, L. A., Basal, L. A., and Allen, M. J. (2017). The role of coordination environment and $\mathrm{pH}$ in tuning the oxidation rate of europium(II). Chem. Eur. J. 23, 1145-1150. doi: 10.1002/chem.201604842

Ekanger, L. A., Mills, D. R., Ali, M. M., Polin, L. A., Shen, Y., Haacke, E. M., et al. (2016a). Spectroscopic characterization of the $3+$ and $2+$ oxidation states of europium in a macrocyclic tetraglycinate complex. Inorg. Chem. 55, 9981-9988. doi: 10.1021/acs.inorgchem.6b00629

Ekanger, L. A., Polin, L. A., Shen, Y., Haacke, E. M., and Allen, M. J. (2016b). Evaluation of $\mathrm{Eu}^{\mathrm{II}}$-based positive contrast enhancement after intravenous, intraperitoneal, and subcutaneous injections. Contrast Media Mol. Imaging 11, 299-303. doi: 10.1002/cmmi.1692

Ekanger, L. A., Polin, L. A., Shen, Y., Haacke, E. M., Martin, P. D., and Allen, M. J. (2015). A Eu ${ }^{\mathrm{II}}$-containing cryptate as a redox sensor in magnetic resonance imaging of living tissue. Angew. Chem. Int. Ed. 54, 14398-14401. doi: 10.1002/anie.201507227

Evans, W. J. (2000). Perspectives in reductive lanthanide chemistry. Coord. Chem. Rev. 206-207, 263-283. doi: 10.1016/S0010-8545(00)00267-8

Facciabene, A., Peng, X., Hagemann, I. S., Balint, K., Barchetti, A., Wang, L.-P., et al. (2011). Tumour hypoxia promotes tolerance and angiogenesis via CCL28 and $\mathrm{T}_{\text {reg }}$ cells. Nature 475, 226-230. doi: 10.1038/nature10169

Fieser, M. E., MacDonald, M. R., Krull, B. T., Bates, J. E., Ziller, J. W., Furche, F., et al. (2015). Structural, spectroscopic, and theoretical comparison of traditional vs recently discovered $\mathrm{Ln}^{2+}$ Ions in the $[\mathrm{K}(2.2 .2-$ cryptand) $]\left[\left(\mathrm{C}_{5} \mathrm{H}_{4} \mathrm{SiMe}_{3}\right)_{3} \mathrm{Ln}\right]$ complexes: the variable nature of $\mathrm{Dy}^{2+}$ and $\mathrm{Nd}^{2+}$ J. Am. Chem. Soc. 137, 369-382. doi: 10.1021/ja510831n

Funk, A. M., Clavijo Jordan, V., Sherry, A. D., Ratnakar, S. J., and Kovacs, Z. (2016). Oxidative conversion of a europium(II)-based $T_{1}$ agent into a europium(III)based paraCEST agent that can be detected in vivo by magnetic resonance imaging. Angew. Chem. Int. Ed. 55, 5024-5027. doi: 10.1002/anie.201511649
Gál, M., Kielar, F., Sokolová, R., Ramešová, Š., and Kolivoška, V. (2013). Electrochemical study of $\mathrm{Eu}^{\mathrm{III}} / \mathrm{Eu}^{\mathrm{II}}$ redox properties of complexes with potential MRI ligands. Eur. J. Inorg. Chem. 2013, 3217-3223. doi: 10.1002/ejic.201300252

Gamage, N. D., Mei, Y., Garcia, J., and Allen, M. J. (2010). Oxidatively stable, aqueous europium(II) complexes through steric and electronic manipulation of cryptand coordination chemistry. Angew. Chem. Int. Ed. 49, 8923-8925. doi: 10.1002/anie.201002789

Gansow, O. A., Kausar, A. R., Triplett, K. M., Weaver, M. J., and Yee., E. L. (1977). Synthesis and chemical properties of lanthanide cryptates. J. Am. Chem. Soc. 99, 7087-7089. doi: 10.1021/ja00463a065

Garcia, J., and Allen, M. J. (2012a). Developments in the coordination chemistry of europium(II). Eur. J. Inorg. Chem. 2012, 4550-4563. doi: 10.1002/ejic.201200159

Garcia, J., and Allen, M. J. (2012b). Interaction of biphenyl-functionalized $\mathrm{Eu}^{2+}$-containing cryptate with albumin: implications to contrast agents in magnetic resonance imaging. Inorg. Chim. Acta 393, 324-327. doi: 10.1016/j.ica.2012.07.006

Garcia, J., Kuda-Wedagedara, A. N. W., and Allen, M. J. (2012). Physical properties of $\mathrm{Eu}^{2+}$-containing cryptates as contrast agents for ultrahighfield magnetic resonance imaging. Eur. J. Inorg. Chem. 2012, 2135-2140. doi: 10.1002/ejic.201101166

Garcia, J., Neelavalli, J., Haacke, E. M., and Allen, M. J. (2011). Eu ${ }^{\mathrm{II}}$-containing cryptates as contrast agents for ultra-high field strength magnetic resonance imaging. Chem. Commun. 47, 12858-12860. doi: 10.1039/c1cc15219j

Green, K. (2018). Cyclic Voltammetry (CV). Cambridge, MA: JoVE Science Education Database. Analytical Chemistry. JoVE.

Harris, D. C. (2003). Quantitative Chemical Analysis, 6th Edn. New York, NY: W. H. Freeman and Company.

Jenks, T. C., Bailey, M. D., Hovey, J. L., Fernando, S., Basnayake, G., Cross, M. E., et al. (2018). First use of a divalent lanthanide for visible-light-promoted photoredox catalysis. Chem. Sci. 9, 1273-1278. doi: 10.1039/C7SC02479G

Jiang, J., Higashiyama, N., Machiida, K., and Adachi, G., (1998). The luminescent properties of divalent europium complexes of crown ethers and cryptands. Coord. Chem. Rev. 170, 1-29. doi: 10.1016/S0010-8545(98)00 $070-8$

Jin, G X., Bailey, M. D., and Allen, M. J. (2016). Unique Eu(II) coordination environments with a janus cryptand. Inorg. Chem. 55, 9085-9090. doi: 10.1021/acs.inorgchem.6b01659

Kawasaki, K., Sugiyama, R., Tsuji, T., Iwasa, T., Tsunoyama, H., Mizuhata, Y., et al. (2017). A designer ligand field for blue-green luminescence of organoeuropium(II) sandwich complexes with cyclononatetraenyl ligands. Chem. Commun. 53, 6557-6560. doi: 10.1039/C7CC03045B

Kelly, R. P., Bell, T. D. M., Cox, R. P., Daniels, D. P., Deacon, G. B., Jaroscik, F., et al. (2015). Divalent tetra- and penta-phenylcyclopentadienyl europium and samarium sandwich and half-sandwich complexes: synthesis, characterization, and remarkable luminescence properties. Organometallics 34, 5624-5636. doi: 10.1021/acs.organomet.5b00842

Kuda-Wedagedara, A. N., and Allen, M. J. (2014). Enhancing magnetic resonance imaging with contrast agents for ultra-high field strengths. Analyst 139, 4401-4410. doi: 10.1039/C4AN00990H

Kuda-Wedagedara, A. N., Wang, C., Martin, P. D., and Allen, M. J. (2015). Aqueous Eu(II)-containing complex with bright yellow luminescence. J. Am. Chem. Soc. 137, 4960-4963. doi: 10.1021/jacs.5b02506

Lauffer, R. B. (1987). Paramagnetic metal complexes as water proton relaxation agents for NMR imaging: theory and design. Chem. Rev. 87, 901-927. doi: $10.1021 /$ cr00081a003

Layfield, R. A., and Murugesu, M., (eds.). (2015). Lanthanides and Actinides in Molecular Magnetism. Weinheim: Wiley-VCH Verlag GmbH \& Co.

le Masne de Chermont Q., Chanéac, C., Seguin, J., Pellé, F., Maîtrejean, S., Jolivet, J. P., et al. (2007). Nanoprobes with near-infrared persistent luminescence for in vivo imaging. Proc. Natl. Acad. Sci. U.S.A. 104, 9266-9271. doi: $10.1073 /$ pnas. 0702427104

Lenora, C. U., Carniato, F., Shen, Y., Latif, Z., Haacke, E. M., Martin, P. D., et al. (2017). Structural features of $\mathrm{Eu}^{\mathrm{II}}$-containing cryptates that influence relaxivity. Chem. Eur. J. 23, 15404-15414. doi: 10.1002/chem.201702158

Lin, M. T., and Beal, M. F. (2006). Mitochondrial dysfunction and oxidative stress in neurodegenerative diseases. Nature 443, 787-795. doi: 10.1038/nature05292 
MacDonald, M. R., Bates, J. E., Ziller, J. W., Furche, F., and Evans, W. J. (2013). Completing the series of +2 ions for the lanthanide elements: synthesis of molecular complexes of $\mathrm{Pr}^{2+}, \mathrm{Gd}^{2+}, \mathrm{Tb}^{2+}$, and $\mathrm{Lu}^{2+}$. J. Am. Chem. Soc. 135, 9857-9868. doi: 10.1021/ja403753j

Mattson, M. P. (2004). Pathways towards and away from Alzheimer's disease. Nature 430, 631-639. doi: 10.1038/nature02621

McCoy, H. N. (1935). The separation of europium from other rare earths. J. Am. Chem. Soc. 57:1756. doi: 10.1021/ja01312a506

Pan, C. L., Pan, Y. S., Wang, J., and Song, J. F. (2011). A heterometallic sandwich complex of europium(II) for luminescent studies. Dalton Trans. 40, 6361-6363. doi: $10.1039 / \mathrm{cldt} 10635 \mathrm{j}$

Park, L., Zhou, P., Pitstick, R., Capone, C., Anrather, J., Norris, E. H., et al. (2008). Nox2-Derived radicals contribute to neurovascular and behavioral dysfunction in mice overexpressing the amyloid precursor protein. Proc. Natl. Acad. Sci. U.S.A. 105, 1347-1352. doi: 10.1073/pnas.0711568105

Pierre, V. C., and Allen, M. J., (eds.). (2018).Contrast Agents for MRI: Experimental Methods. Cambridge: Royal Society of Chemistry.

Pierre, V. C., Allen, M. J., and Caravan, P. (2014). Contrast agents for MRI: $30+$ years and where are we going? J. Biol. Inorg. Chem. 19, 127-131. doi: 10.1007/s00775-013-1074-5

Regueiro-Figueroa, M., Barriada, J. L., Pallier, A., Esteban-Gómez, D., Blas, A., Rodríguez-Blas, T., et al. (2015). Stabilizing divalent europium in aqueous solution using size-discrimination and electrostatic effects. Inorg. Chem. 54, 4940-4952. doi: 10.1021/acs.inorgchem.5b00548

Renny, J. S., Tomasevich, L. L., Tallmadge, E. H., and Collum, D. B. (2013). Method of continuous variations: applications of job plots to the study of molecular associations in organometallic chemistry. Angew. Chem. Int. Ed. 52, 11998-12013. doi: 10.1002/anie.201304157

Sabbatini, N., Ciano, M., Dellonte, S., Bonazzi, A., and Balzani, V. (1982). Absorption and emission properties of a europium(II) cryptate in aqueous solution. Chem. Phys. Lett. 90, 265-268. doi: 10.1016/0009-2614(82)83236-3

Sabbatini, N., Ciano, M., Dellonte, S., Bonazzi, A., Bolletta, F., and Balzani, V. (1984). Photophysical properties of europium(II) cryptates. J. Phys. Chem. 88, 1534-1537. doi: 10.1021/j150652a018

Shipley, C. P., Capecchi, S., Salata, O. V., Etchells, M., Dobson, P. J., and Christou, V. (1999). Orange electroluminescence from a divalent europium complex. Adv. Mater. 11, 533-536. doi: 10.1002/(SICI) 1521-4095(199905)11:73.0.CO;2-U

Shriver, D. F., and Drezdzon, M. A. (1986). The Manipulation of Air-Sensitive Compounds. New York, NY: John Wiley \& Sons, Inc.

Shweiki, D., Itin, A., Soffer, D., and Keshet, E. (1992). Vascular endothelial growth factor induced by hypoxia may mediate hypoxia-initiated angiogenesis. Nature 359, 843-845. doi: 10.1038/359843a0
Soderholm, L., Antonio, M. R., Skanthakumar, S., and Williams, C. W. (2002). Correlated electrons in the Eu-exchanged Preyssler anion $\left[\mathrm{EuP}_{5} \mathrm{~W}_{30} \mathrm{O}_{110}\right]^{\mathrm{n}-}$ J. Am. Chem. Soc. 124, 7290-7291. doi: 10.1021/ja025821d

Teprovich, J. A. Jr., Antharjanam, P. K. S., Prasad, E., Pesciotta, E. N., and Flowers, R. A. II. (2008). Generation of $\mathrm{Sm}^{\mathrm{II}}$ reductants using high intensity ultrasound. Eur. J. Inorg. Chem. 2018, 5015-5019. doi: 10.1002/ejic.2008 00876

Tóth, É., Burai, L., and Merbach, A. E. (2001). Similarities and differences between the isoelectronic $\mathrm{Gd}^{\mathrm{III}}$ and $\mathrm{Eu}^{\mathrm{II}}$ complexes with regard to MRI contrast agent applications. Coord. Chem. Rev. 216-217, 363-382. doi: 10.1016/S0010-8545(01)00312-5

Vanek, J., Smrčka, F., Lubal, P., Trískov,á, I., and Trnkov,á, L. (2016). Dual carbonate sensor based on $\mathrm{Eu}(\mathrm{III})$ complex of DO3A ligand. Monatsh. Chem. 147, 925-934. doi: 10.1007/s00706-016-1722-X

Wang, J., Ma, Q., Wang, Y., Shen, H., and Yuan, Q. (2017). Recent progress in biomedical applications of persistent luminescence nanoparticles. Nanoscale 9 , 6204-6218. doi: 10.1039/C7NR01488K

Yee, E. L., Cave, R. J., Guyer, K. L., Tyma, P. D., and Weaver, M. J. (1979). A survey of ligand effects upon the reaction entropies of some transition metal redox couples. J. Am. Chem. Soc. 101, 1131-1137. doi: 10.1021/ja0049 $9 \mathrm{a} 013$

Yee, E. L., Gansow, O. A., and Weaver, M. J. (1980). Electrochemical studies of europium and ytterbium cryptate formation in aqueous solution. Effects of varying the metal oxidation state upon cryptate thermodynamics and kinetics. J. Am. Chem. Soc. 102, 2278-2285. doi: 10.1021/ja00527a024

Yee, E. L., Hupp, J. T., and Weaver, M. J. (1983). The nonadiabicity question for Europium(III/II): outer-sphere reactivities of Europium (III/II) cryptates. Inorg. Chem. 22, 3465-3470. doi: 10.1021/ic00165a020

Zucchi, G., Thuéry, P., Rivière, E., and Ephritikhinea, M. (2010). Europium(II) compounds: simple synthesis of a molecular complex in water and coordination polymers with 2,2'-bipyrimidine-mediated ferromagnetic interactions Chem. Commun. 46, 9143-9145. doi: 10.1039/c0cc02539a

Conflict of Interest Statement: The authors declare that the research was conducted in the absence of any commercial or financial relationships that could be construed as a potential conflict of interest.

Copyright (c) 2018 Basal and Allen. This is an open-access article distributed under the terms of the Creative Commons Attribution License (CC BY). The use, distribution or reproduction in other forums is permitted, provided the original author(s) and the copyright owner are credited and that the original publication in this journal is cited, in accordance with accepted academic practice. No use, distribution or reproduction is permitted which does not comply with these terms. 